\title{
Decomposition and biological colonization of native and exotic leaf litter in a Central Spain stream
}

\author{
Silvia Medina-Villar ${ }^{1, *}$, Álvaro Alonso ${ }^{1}$, Beatriz R. Vázquez de Aldana $^{2}$, Esther Pérez-Corona ${ }^{3}$ \\ and Pilar Castro-Díez ${ }^{1}$
}

${ }^{1}$ Departamento de Ciencias de la Vida (Unidad Docente de Ecología), Facultad de Ciencias, Universidad de Alcalá. 28871, Alcalá de Henares, Madrid, España.

${ }^{2}$ Instituto de Recursos Naturales y Agrobiología de Salamanca (IRNASA-CSIC), 37008 Salamanca, España.

${ }^{3}$ Departamento de Ecología, Facultad de Ciencias Biológicas, Universidad Complutense de Madrid, 28040, Madrid, España.

* Corresponding author: medina_villar@hotmail.com

Received: 11/07/2014

Accepted: 16/01/2015

\begin{abstract}
Decomposition and biological colonization of native and exotic leaf litter in a Central Spain stream

Riparian invasion by exotic trees may lead to changes in the quality of leaf-litter inputs to freshwater ecosystems. Leaflitter inputs are especially important in headwater streams, where aquatic food webs largely depend on the organic matter provided by the terrestrial vegetation. In a headwater stream of Central Spain, North of Guadalajara Province (Tagus basin) we compared the decomposition and biological colonization of leaf litter among two exotic (Ailanthus altissima Mill. Swingle and Robinia pseudoacacia L.) and two native trees (Fraxinus angustifolia Vahl. and Populus alba L.) co-existing in riparian zones. We hypothesized a lower biological colonization of exotic leaves due to organisms have not co-evolved with the exotic trees according to the Novel Weapons Hypothesis (NWH) and, consequently, lower decomposition rates of exotic leaves. To test our hypothesis, litter bags with different mesh sizes (coarse $(\mathrm{C})$ and fine $(\mathrm{F})$ ), were used to distinguish between the total and microbial decomposition. The litter bags were placed in the stream and recovered after 2, 20,39,62 and 82 days of incubation. After each collection, we assessed the amount of remaining litter, analysed the nitrogen $(\mathrm{N})$ and phosphorous $(\mathrm{P})$ in the litter, identified the macroinvertebrates and quantified the fungal biomass. Consistent with our hypothesis, we found greater fungal biomass buildup on native leaves than on exotic leaves. However, decomposition rates $(k)$ were species-specific, being the ranking in C-bags (A. altissima $=F$. angustifolia $>P$. alba $>$ R. pseudoacacia) slightly different than in F-bags $(A$. altissima $>$ F. angustifolia $>$ P. alba $>$ R. pseudoacacia). The $\mathrm{k}$ in both the C-bags and F-bags were correlated with leaf traits, such as lignin, acid detergent fibre (ADF) and lignin:P. There was not a clear effect of the exotic species on macroinvertebrate variables, but the contribution of macroinvertebrates to litter decomposition was lower in exotic litter than in native litter, as shown by a lower ratio between $k$ in C-bags and $k$ in F-bags $\left(k_{\mathrm{C}}: k_{\mathrm{F}}\right)$. Our results supported that invasive species might impact both biological colonization and decomposition rates in stream ecosystems by the addition of different quality leaf litter when compared to native vegetation. The differences in the biological colonization may be explained by the $\mathrm{NWH}$, but differences in the decomposition rates were better explained by litter quality.
\end{abstract}

Key words: Ailanthus altissima, freshwater ecosystem, fungal biomass, invasive species, leaf quality, macroinvertebrate community, Robinia pseudoacacia.

\section{RESUMEN}

Descomposición y colonización biológica de hojarasca nativa y exótica en un arroyo del centro de España

La invasión de las riberas por árboles exóticos puede provocar cambios en la calidad de las entradas de hojarasca a los ecosistemas de agua dulce, especialmente importantes en arroyos de cabecera, donde las redes tróficas dependen en gran medida de los aportes de materia orgánica proporcionada por la vegetación terrestre. En un arroyo de cabecera del Centro de España, Norte de la provincia de Guadalajara (Cuenca del Tajo), comparamos entre la descomposición y colonización biológica de la hojarasca de dos árboles exóticos (Ailanthus altissima Mill. Swingle y Robinia pseudoacacia L.) y dos nativos (Fraxinus angustifolia Vahl. y Populus alba L.), que coexisten en zonas de ribera. Hipotetizamos que habrá una menor 
colonización biológica de las hojas exóticas debido a que los organismos del arroyo no han co-evolucionado con los árboles exóticos de acuerdo con la Hipótesis de las Nuevas Armas (NWH) y, por tanto, menores tasas de descomposición de éstas. Para testar nuestra hipótesis, se sumergieron en el arroyo bolsas de descomposición con distinta de luz de malla, gruesa (C) y fina $(F)$-usadas para distinguir entre descomposición total y microbiana- y se recuperaron después de 2, 20, 39, 62 y 82 días de incubación. Después de la recolección pesamos la cantidad de hojarasca remanente, analizamos el nitrógeno $(N)$ y fósforo $(P)$ de la hojarasca, identificamos los macroinvertebrados y cuantificamos la biomasa fúngica. De acuerdo con nuestra hipótesis, encontramos mayor biomasa fúngica acumulada en hojas nativas que en exóticas. Sin embargo, la tasa de descomposición (k) fue específica de la especie, siendo el ranking en las bolsas $C$ (A. altissima $=\mathrm{F}$. angustifolia $>\mathrm{P}$. alba $>$ R. pseudoacacia) ligeramente diferente al de las bolsas $F$ (A. altissima $>$ F. angustifolia $>$ P. alba $>$ R. pseudoacacia). Ambas k (en bolsas $C$ y $F$ ) se correlacionaron con lignina, fibra ácido detergente (ADF) y lignina:P. No hubo un efecto claro de las especies exóticas sobre las variables de macroinvertebrados, pero la contribución de los macroinvertebrados a la descomposición fue menor en la hojarasca exótica que en la nativa, como muestra el menor ratio entre $k$ en bolsas C y $F\left(\mathrm{k}_{C}: \mathrm{k}_{F}\right)$. Nuestros resultados apoyan que las especies invasoras pueden impactar tanto la colonización biológica como las tasas de descomposición de la hojarasca en los ecosistemas de arroyos mediante el aporte de hojarasca de distinta calidad respecto de la vegetación nativa. Las diferencias en colonización biológica pueden ser explicadas por la NHW pero las diferencias en descomposición son mejor explicadas por la calidad de la hojarasca.

Palabras clave: Ailanthus altissima, ecosistemas de agua dulce, biomasa fúngica, especies invasoras, calidad de la hoja, comunidad de macroinvertebrados, Robinia pseudoacacia.

\section{INTRODUCTION}

Litter inputs into streams from riparian areas represent the main food source for heterotrophic communities in headwater streams, where the shade cast by riparian canopies limits autochthonous primary production (Wallace et al., 1997). In temperate deciduous forest, fallen leaves during autumn are the main component of the litter inputs (Abelho, 2001). When leaf litter falls into a stream, a complex decomposition process begins which involves an initial leaching of soluble compounds, followed by physical abrasion and colonization by microbes and invertebrates (Webster \& Benfield, 1986). The rate of leaf decomposition depends on the local climatic conditions, water properties, biotic communities, and the quality of the leaves (Webster \& Benfield, 1986). Leaf chemical composition (e.g., content of nitrogen $(\mathrm{N})$, phosphorous $(\mathrm{P})$, phenolic compounds, and lignin), along with physical properties (e.g., leaf toughness, leaf mass per unit of area, and density) represent the leaf quality, which is a major factor determining the decomposability of leaves (Enriquez et al., 1993; Ostrofsky, 1997; Graça \& Canhoto, 2006; Bottollier-Curtet et al., 2011).
The quality of leaf litter may affect aquatic detritivores. For instance, leaf secondary compounds, such as polyphenols or essential oils, may delay or inhibit fungal growth (Graça et al., 2002; Mathuriau \& Chauvet, 2002), which in turn may affect leaf consumption by macroinvertebrates because microbial colonization (i.e., conditioning) make leaves more palatable to detritivores (Arsuffi \& Suberkropp, 1989; Wright \& Covich, 2005). Moreover, it was reported that aquatic macroinvertebrates preferentially consumed soft leaves with high $\mathrm{N}$ content and low amounts of structural carbon (Motomori et al., 2001; Rincón \& Martínez, 2006). The growth and survival of macroinvertebrates increased with the consumption of such high-quality leaves (Albariño \& Balseiro, 2002; Going \& Dudley, 2008). The density and diversity of invertebrates may be directly affected by exotic trees bearing leaves with high secondary compounds, as is the case of Eucalyptus spp. (Larrañaga et al., 2009; Gama et al., 2014). However, in the Eucalyptus spp. native range, the diversity of invertebrates was reduced by the introduction of the exotic Salix spp. (Read \& Barmuta, 1999). The negative effect of eucalyptus on invertebrates in its exotic range, but not in its native range, suggested that 
invertebrates in the native range were adapted to the chemicals present in Eucalyptus spp. leaves, which were novel for those in the exotic range. In this context, the Novel Weapons Hypothesis (NWH) described by Callaway \& Ridenour (2004) predicts that secondary chemical compounds produced by exotic species affect microorganisms and invertebrates in their areas of introduction because these organisms are not adapted to these compounds.

Riparian ecosystems are highly vulnerable to exotic plant invasion (Hood \& Naiman, 2000) due to their milder microclimatic conditions and the frequent natural and anthropogenic disturbances that create diverse niches to support invasive species (Planty-Tabacchi et al., 1996; Chytrý et al., 2008). Vegetation destruction by human activities additionally increases the invasibility of these systems, creating gaps that can be readily colonized by light-demanding invaders (LindigCisneros \& Zedler, 2001). Floodplain invasions by exotic trees may alter the quality of leaf litter inputs into streams, thus causing effects on heterotrophic communities and nutrient cycles (Bailey et al., 2001; Hladyz et al., 2009). Those effects will depend on the magnitude and direction of the leaf quality differences between the exotic and the native species (Hladyz et al., 2009).

Ailanthus altissima Mill. Swingle (Simaroubaceae) and Robinia pseudoacacia L. (Fabaceae) are two aggressive invasive tree species in many regions of the world, and they usually invade riparian areas (Sanz-Elorza et al., 2004; GEIB, 2006; DAISIE, 2009). A. altissima is native to Southeast Asia and R. pseudoacacia is native to the East and Central United States (Kowarik \& Säumel, 2007; Cierjacks et al., 2013). Some of the traits that may contribute to their invasive potential are the production of phytotoxic compounds (De Feo et al., 2003; Nasir et al., 2005), a profuse resprouting capacity and, in the case of $R$. pseudoacacia, the ability to fix atmospheric $\mathrm{N}_{2}$, which is very useful in nutrient-poor soils (Rice et al., 2004; Kowarik \& Säumel, 2007; Cierjacks et al., 2013). Both exotics are in the Atlas of exotic invasive plants in Spain (Sanz-Elorza et al., 2004), and they cooccur with native riparian trees, such as Fraxinus angustifolia Vahl. (Oleaceae) and Populus alba L. (Salicaceae).

Some studies have investigated the effect of A. altissima and $R$. pseudoacacia on riparian soils and on lentic ecosystems of Central Spain (Castro-Díez et al., 2011; Alonso et al., 2010), but studies on stream ecosystems, which are highly depend on terrestrial inputs from riparian vegetation, are scarce (see Swan et al., 2008). Moreover, studies about the effect of A. altissima and $R$. pseudoacacia on the fungal colonization of leaves are lacking, even when aquatic fungi are an important component involved in leaf decomposition (Abelho, 2001; Cornut et al., 2010).

The aim of this study was to assess the impacts of A. altissima and R. pseudoacacia on key functions of a stream ecosystem in Central Spain. Specifically, we compared leaf decomposition rates, fungal and macroinvertebrate colonization, and nutrient dynamics between exotic and two common native tree species ( $F$. angustifolia and P. alba). Because leaf quality is the main factor determining leaf decomposition through the effect on macroinvertebrates and fungi, the differences in some leaf traits among species were also explored. We hypothesized that exotic leaf litter would show lower fungal and macroinvertebrate colonization than native leaf litter, given that stream organisms have not coevolved with the exotic tree secondary compounds (NWH; Callaway \& Ridenour, 2004) and, consequently, the decomposition rates of the exotic leaf litter in the stream were expected to be lower than those of the native leaf litter.

\section{MATERIAL AND METHODS}

\section{Study area and leaf collection}

On autumn 2010, we performed the experiment at the Alboreca Stream, in the upper basin of the Henares River (Guadalajara, Spain; latitude $41^{\circ} 8^{\prime} \mathrm{N}$, longitude $2^{\circ} 36^{\prime} \mathrm{W}$, elevation $1056 \mathrm{~m}$ ). The climate in the area is Mediterranean pluviseasonal-oceanic, with mean maximum and minimum annual temperatures of $31.5^{\circ} \mathrm{C}$ and $-2.1^{\circ} \mathrm{C}$, respectively, and a mean annual preci- 
pitation of $601 \mathrm{~mm}$ (Worldwide Bioclimatic Classification System, http://www.globalbiocli matics.org). The riparian vegetation of the upper basin of the Henares River is characterized by native trees $P$. alba and $F$. angustifolia, with some patches invaded by the exotic tree species A. altissima and R. pseudoacacia. At the study site, the floodplain is mostly occupied by crops and Populus $x$ euramericana plantations.

The wetted width, stream depth and current velocity of the study site were measured at the beginning and the end of the experiment using a metre stick and a portable velocitymeter (Series P600, Dostmann electronic GmbH, Ladytown, Ireland). The maximum and minimum water temperatures, $\mathrm{pH}$, conductivity and nutrient concentrations were monitored during the leaf litter decomposition experiment on each collection date. The water temperature was measured with an outdoor maximum/minimum thermometer placed inside the stream. In the laboratory, the stream water $\mathrm{pH}$ and conductivity were measured with a pH meter (Crison micropH 2001) and a conductivity meter (Crison conductivity meter 524), respectively. The water nitrate, ammonium and ortho-phosphate were measured using photometric methods (Spectroquant ${ }^{\mathrm{R}}$ test).

Senescent leaves, i.e., those which detach with a gentle touch, from R. pseudoacacia, A. altissima, F. angustifolia and P. alba were collected in October 2009 from the riparian forest along the low stretch of the Henares River (near the city of Alcalá de Henares, Madrid, Spain). For each species, leaves were collected from multiple trees, pooled and air-dried at room temperature. Rachises from compound leaves (A. altissima, $F$. angustifolia and $R$. pseudoacacia) and petioles of $P$. alba were removed to homogenize the leaf sampling used for this experiment. Although we only used leaf laminas, we will refer to them as "leaves" throughout the paper.

\section{Leaf litter decomposition}

Air-dried leaves from each tree species were incubated in the stream using bags with two different mesh sizes: 1) fine mesh bags (F-bags) of $12 \times 12 \mathrm{~cm}$ were made with $1.2 \mathrm{~mm}$ nylon mesh size, which excluded macroinvertebrate access and allowed only microbial decomposition; and 2) coarse mesh bags (C-bags) of $17 \times 17 \mathrm{~cm}$ were made with high density $5 \mathrm{~mm}$ polyethylene mesh size and allowed both microbial and macroinvertebrate processing. Each bag was filled with approximately $2 \mathrm{~g}$ of senescent air-dried leaves of a single species. On 12 November 2010, a total of 252 litter bags were placed in 2 stream riffles, separated $15 \mathrm{~m}$ from each other. Among them, 160 litter bags (4 leaf species $\times 2$ types of litter bags $\times 5$ collections $\times 4$ replicates) were used to assess litter decomposition and to identify the macroinvertebrates colonizing the litter material. Seventy-two additional litter bags (4 leaf species $\times 2$ types of litter bags $\times 3$ collections $\times 3$ replicates) were used for the fungal biomass estimation (see below). The remaining 20 bags were empty C-bags (5 collections $\times 4$ replicates) that were used as a control for the macroinvertebrates that used the bags as refuge. Each replicated bag (1 per species, litter bag type and collection) was fixed in a random position to one of two chains, fastened to one of four concrete blocks. Half of these blocks were placed in each riffle. In this way, the potential effect of the riffle and the block on litter decomposition and colonization was homogeneously distributed among species, bag types and collections. Litter bags were collected after 2, 20, 39, 62, and 82 days of incubation by means of a hand net. Before the third collection, there was a sudden rise of the water flow (detected $40 \mathrm{~km}$ downstream 12 days before the $3^{\text {rd }}$ collection by Bujalaro gauging station), which moved all of the concrete blocks from their initial position, and possibly dragged part of the invertebrates which had already colonized the litter bags. However, no litter bag or its content was lost. Three days before the third collection, the blocks were placed back in their initial positions to keep the initial site conditions. After each collection, samples were stored in polyethylene zipper bags, transported and kept cold $\left(5^{\circ} \mathrm{C}\right)$ until processing. Once in the laboratory, the litter bags were gently rinsed with tap water over a $250 \mu \mathrm{m}$ sieve to separate the macroinvertebrates from the leaves. Macroinvertebrates were preserved in a $3 \%$ formaldehyde solution until they were iden- 
tified to the family level using the method in Tachet et al. (2003). Macroinvertebrates were additionally classified into the following functional feeding groups (FFG): shredders ( $\mathrm{SH})$, collectorgatherers $(\mathrm{CG})$, collector-filterers $(\mathrm{CF})$, scrapers (SC) and predators (PD), according to Merritt \& Cummins (1996) and Tachet et al. (2003). The leaf mass remaining (LMR) in each bag was oven-dried $\left(\geq 48 \mathrm{~h}\right.$ at $\left.60^{\circ} \mathrm{C}\right)$ and weighed.

\section{Leaf traits}

We assessed the $\mathrm{N}$ and $\mathrm{P}$ concentrations in three 2 g-replicates of the initial senescent leaves and the total remaining leaf mass in each collection and species from C-bags. Samples were oven-dried $\left(\geq 48 \mathrm{~h}\right.$ at $\left.60^{\circ} \mathrm{C}\right)$ to correct for water content and ground with a Culatti mill to a particle size $<0.5 \mathrm{~mm}$. The $\mathrm{N}$ and $\mathrm{P}$ concentrations were determined with a segmented flux auto-analyser (Skalar $\mathrm{San}^{++}$) after a digestion with $\mathrm{H}_{2} \mathrm{SO}_{4}$ and $\mathrm{Cu}-\mathrm{KSO}_{4}$ (Nelson \& Sommers, 1973). Acid detergent fibre (ADF), lignin and total phenolic compounds (TPC) were analysed only in the non-decomposed leaves. ADF and lignin concentrations were determined using the filter bag technique (FBT), with an Ankom Automated Fibre Analyser A2000, based on the analytical method of Goering \& Van Soest (1970). The extraction procedure to determine the TPC was performed in duplicate as follows. Approximately $200 \mathrm{mg}$ of freeze-dried and ground leaves were extracted twice in $5.0 \mathrm{ml}$ of 50:50 (v/v) methanol:water for $30 \mathrm{~min}$ in an ultrasound bath. The mixture was centrifuged and filtered twice through filter paper, and the filtrates were mixed and stored at $-20{ }^{\circ} \mathrm{C}$ until analysis (Waterman \& Mole, 1994). The TPC concentration was assessed by the colorimetric Prussian-blue method using gallic acid as the

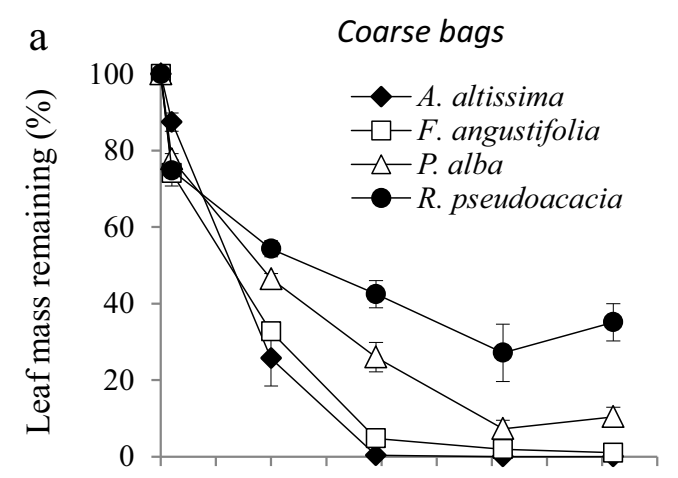

b
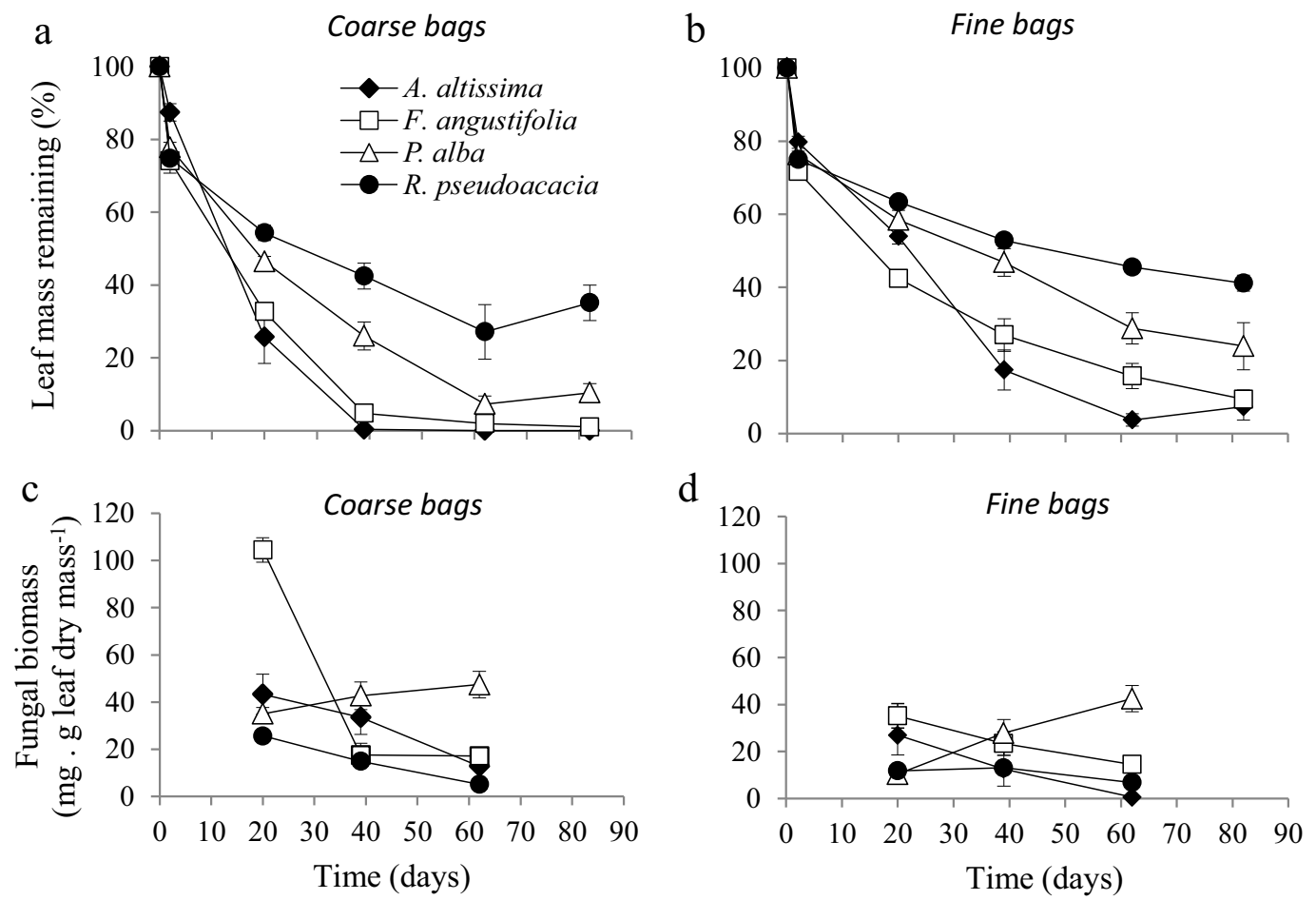

Figure 1. The mean ( \pm SE) leaf mass remaining ( $a$ and $b)$ and fungal biomass (c and d) in the coarse (a and c) and fine (b and d) litter bags for each species over the study period. Black symbols indicate exotic species and white symbols indicate native species. Media $( \pm E E)$ de la masa de hoja remanente (a y b) y de la biomasa fúngica ( $c$ y d) en bolsas de descomposición de luz de malla gruesa $\left(\begin{array}{l}a \\ y\end{array}\right)$ y fina $\left(\begin{array}{ll}b & \text { y }\end{array}\right)$ para cada especie en el periodo de estudio. Los símbolos negros indican especies exóticas y los blancos especies nativas. 
Table 1. Mean values $( \pm$ SE) for initial leaf traits of exotic and native species. $N=$ Nitrogen; $P=$ Phosphorus; TPC $=$ Total phenolic compounds; and ADF = Acid Detergent Fibre. Different letters in a row indicate significant differences among species for each variable (ANOVA test with Tukey HSD, $p<0.05$ ), and they are alphabetically ordered from the highest to the lowest value.

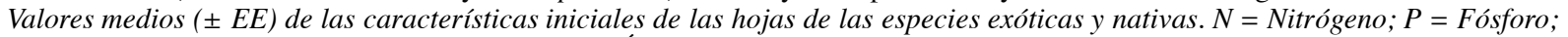
$T P C=$ Compuestos fenólicos totales $; A D F=$ Fibra Ácido Detergente. Diferentes letras en una fila indican diferencias significativas entre especies para cada variable (ANOVA test con Tukey HSD, $\mathrm{p}<0.05$ y están ordenadas alfabéticamente de mayor a menor valor.

\begin{tabular}{ccccc}
\hline & \multicolumn{2}{c}{ Exotics } & Natives \\
\cline { 2 - 5 } Leaf traits & A. altissima & R.pseudoacacia & P.alba & F. angustifolia \\
\hline $\mathrm{N}(\%)$ & $1.51 \pm 0.01^{b}$ & $1.75 \pm 0.01^{a}$ & $0.93 \pm 0.02^{d}$ & $1.00 \pm 0.00^{c}$ \\
$\mathrm{P}(\%)$ & $0.10 \pm 0.01^{a b}$ & $0.07 \pm 0.00^{c}$ & $0.07 \pm 0.00^{b c}$ & $0.15 \pm 0.02^{a}$ \\
Lignin (\%) & $18.1 \pm 0.7^{b}$ & $29.5 \pm 1.5^{a}$ & $32.6 \pm 1.8^{a}$ & $22.2 \pm 0.5^{b}$ \\
ADF (\%) & $23.1 \pm 1.3^{c}$ & $31.7 \pm 0.3^{b}$ & $36.1 \pm 1.1^{a}$ & $26.0 \pm 0.6^{c}$ \\
TPC (\%) & $2.3 \pm 0.4^{a}$ & $2.7 \pm 0.0^{a}$ & $2.2 \pm 0.1^{a}$ & $1.1 \pm 0.0^{b}$ \\
N:P & $14.9 \pm 1.5^{b}$ & $26.3 \pm 0.8^{a}$ & $13.2 \pm 0.5^{b}$ & $6.8 \pm 0.9^{c}$ \\
Lignin:N & $11.9 \pm 0.4^{c}$ & $16.9 \pm 0.9^{b, c}$ & $35.2 \pm 2.3^{a}$ & $22.2 \pm 0.6^{b}$ \\
Lignin:P & $178.9 \pm 23.8^{b}$ & $444.9 \pm 34.9^{a}$ & $465.5 \pm 41.4^{a}$ & $149.8 \pm 16.4^{b}$ \\
\hline
\end{tabular}

standard (Graham, 1992). We calculated the litter quality indices $\mathrm{N}: \mathrm{P}$, lignin:N and lignin:P ratios because they were previously related to decomposition rates and dynamics (Hladyz et al., 2009).

\section{Fungal biomass determination}

The fungal biomass in the litter samples, collected after 20,39 and 62 days in the stream, was estimated from the concentration of ergosterol, a specific component of fungal cell membranes (Ekblad et al., 1998), following the methodology of Gessner (2005). In brief, freeze-dried leaf samples (approximately $0.10 \mathrm{~g}$ ) were placed in tubes with $10 \mathrm{ml}$ of $0.14 \mathrm{M}$ of potassium hydroxide $(\mathrm{KOH})$ in methanol. The mixture was incubated at $80^{\circ} \mathrm{C}$ during $30 \mathrm{~min}$ in a Block Heater (Stuart Scientific). After being cooled, the extract was acidified with $5 \mathrm{ml}$ of $0.75 \mathrm{M}$ of hydrochloric acid $(\mathrm{HCl})$ and transferred into a SPE cartridge (Waters Sep-Pack Vac RC, 500 mg, tC18) pre-conditioned with an acidified extract solution (0.14 M KOH in methanol: $0.75 \mathrm{M} \mathrm{HCl}$; $6: 1 \mathrm{v} / \mathrm{v})$. After the sample addition, the column was washed with $2.5 \mathrm{ml}$ of $0.4 \mathrm{M} \mathrm{KOH}$ in $60 \%$ methanol $(\mathrm{v} / \mathrm{v})$ and dried under a stream of air for approximately $60 \mathrm{~min}$. Ergosterol was eluted into HPLC vials with $1.6 \mathrm{ml}$ of isopropanol. The final separation of ergosterol from the matrix lipids was performed by High Performance Liquid Chromatography (HPLC) with a Waters 2690 system with a Sunfire C18 Waters column $(5 \mu \mathrm{m}$; $5.6 \times 250 \mathrm{~mm}$ ), at $33^{\circ} \mathrm{C}$. The mobile phase was methanol $(100 \%)$ at a flow rate of $1.4 \mathrm{ml} / \mathrm{min}$. Ergosterol was detected at $282 \mathrm{~nm}$ with a Photodiode Array Detector (PDA) Waters 2996.

Table 2. Decomposition rates $(k)$ (Mean $\pm 95 \%$ Confidence interval) in coarse $\left(k_{\mathrm{C}}\right)$ and fine $\left(k_{\mathrm{F}}\right)$ litter bags, the $k_{\mathrm{C}}: k_{\mathrm{F}}$ ratio of the four species; and the $R^{2}$ coefficient of each regression line fitted to calculate $k$. Different letters in a column indicate significant differences among species $\left(p<0.05\right.$, overlap test). For each species, significant differences between $k_{\mathrm{C}}$ and $k_{\mathrm{F}}(p<0.05$, overlap test) are indicated by an asterisk. Tasas de descomposición (k) (Media \pm Intervalo de confianza al $95 \%$ ) en bolsas de luz de malla gruesa $\left(\mathrm{k}_{C}\right)$ y fina $\left(\mathrm{k}_{F}\right)$, el ratio $\mathrm{k}_{C}: \mathrm{k}_{F}$ de las cuatro especies y el coeficiente $\mathrm{R}^{2}$ de cada línea de regresión ajustada para calcular k. Diferentes letras en una columna indican diferencias significativas entre especies ( $\mathrm{p}<0.05$; test de solapamiento). Para cada especie diferencias significativas entre $\mathrm{k}_{C} y \mathrm{k}_{F}(\mathrm{p}<0.05$; test de solapamiento) están indicadas por medio de un asterisco.

\begin{tabular}{|c|c|c|c|c|c|}
\hline \multirow[b]{2}{*}{ Species } & \multicolumn{4}{|c|}{ Decomposition rate } & \multirow[t]{2}{*}{$k_{\mathrm{C}}: k_{\mathrm{F}}$} \\
\hline & $-k_{\mathrm{C}}($ Mean $(95 \% \mathrm{CI}))$ & $R^{2}$ & $-k_{\mathrm{F}}(\operatorname{Mean}(95 \% \mathrm{CI}))$ & $R^{2}$ & \\
\hline A. altissima & $0.080(0.062-0.098)^{a}$ & 0.87 & $0.053(0.040-0.066)^{a}$ & 0.84 & 1.51 \\
\hline R.pseudoacacia* & $0.017(0.012-0.022)^{d}$ & 0.80 & $0.008(0.007-0.009)^{d}$ & 0.95 & 2.07 \\
\hline P. alba* & $0.040(0.029-0.051)^{c}$ & 0.82 & $0.016(0.012-0.020)^{c}$ & 0.84 & 2.50 \\
\hline F. angustifolia * & $0.069(0.058-0.081)^{a}$ & 0.93 & $0.028(0.022-0.034)^{b}$ & 0.89 & 2.43 \\
\hline
\end{tabular}


The fungal biomass concentration was estimated using the conversion factor of $5.5 \mathrm{mg}$ ergosterol per gram of fungal dry mass (Gessner \& Chauvet, 1993).

\section{Statistical analysis}

An analysis of covariance (ANCOVA) was performed, using time as a covariate, to assess the effect of the two factors (litter bag and species) on the percentage of leaf mass remaining (\% LMR), as a dependent variable. The \% LMR was transformed $(\ln (x+1))$ to meet the linearity assumption for ANCOVA, and it was fitted with time to calculate the decomposition rates $(k)$ in C-bags and F-bags ( $k_{\mathrm{C}}$ and $k_{\mathrm{F}}$, respectively). We considered that two species differed in $k$ when their $95 \%$ confident intervals did not overlap. The ratio $k_{\mathrm{C}}: k_{\mathrm{F}}$ was considered as a proxy measurement of the effect of macroinvertebrates on leaf litter decomposition, although the physical abrasion by water flow was also a factor that affected litter decomposition and acted in a greater extent in C-bags than in F-bags (Hladyz et al., 2009). Therefore, changes in the $k_{\mathrm{C}}: k_{\mathrm{F}}$ ratio across species implied shifts in the relative contribution of microorganisms and shredders to litter decomposition (Gessner \& Chauvet, 2002). We did not use the last collection ( 82 days) in the analysis because there were no remains of $A$. altissima and $F$. angustifolia leaves and increments in \% LMR were noticed in R. pseudoacacia and P. alba, likely due to $\mathrm{CaCO}_{3}$ precipitation (Casas \& Gessner, 1999). Differences among species in the initial leaf traits were assessed by one-way analysis of variance (ANOVA) followed by a Tukey Honestly Significant Difference (HSD) test. To meet the ANOVA assumptions, the $\mathrm{P}$ concentration was Ln transformed. Pearson correlations between leaf traits and $k$ were performed to determine which traits controlled leaf decomposition. The differences in the $\mathrm{N}$ and $\mathrm{P}$ concentrations of the decomposed leaves among species and time were assessed by a two-way ANOVA (species $\times$ time), followed by a Tukey HSD test. The differences in the fungal biomass were assessed by a three-way ANOVA (species $x$ litter bag $\times$ time), followed by a Tukey HSD test.
The differences in the total density (number of individuals per litter bag) and richness (number of macroinvertebrate families per litter bag) were assessed using a two-way ANOVA (species $x$ time). To meet the ANOVA assumptions, the density of macroinvertebrate families were logtransformed. A generalized linear model (GLM, Poisson distribution, log link) was used to evaluate the differences in the relative abundance of shredders across species and time. These analyses included the control (empty bags) as a level of the factor species.

To search for patterns among the macroinvertebrate communities colonizing the different leaf species, a two-dimensional non-metric multidimensional scaling ordination (NMDS) (McCune \& Grace, 2002) was performed on the mean relative abundance of the macroinvertebrate families (number of individuals of a family per total number of individuals in litter bag). Macroinvertebrate families that occurred in less than $5 \%$ of the C-bags (i.e., 26 out of 42 families) were omitted to reduce the effect of rare taxa on the ordination (McCune \& Grace, 2002). The mean relative abundances of the used families per litter species and collection are available in the Supplementary information (Table S1 at www.limnetica.net/internet). The sample positions on the NMDS biplot were calculated by Euclidean distances from the original data. Fifteen iterations were run to achieve a stress value of 0.15 , which was considered satisfactory in Community Ecology (McCune \& Grace, 2002). Pearson correlations between the mean relative abundance of each macroinvertebrate family and each axis of NMDs were performed to assess which macroinvertebrate families had further weight on the ordination. Families with $R^{2}>0.6$ and a significant correlation $(p<0.05)$ were considered to be the most influential on the ordination. Permutational multivariate analysis of variance (perMANOVA), using Bray-Curtis distance matrices, was applied to the relative abundance of macroinvertebrate families used in the NMDS to assess the differences across species and time in the macroinvertebrate community structure. R package 2.14.0 (R Development Core Team, 2011) was used for NMDS ordina- 
Table 3. The results of a two-way ANOVA (species and time) for nitrogen $(\mathrm{N})$ and phosphorous $(\mathrm{P})$ concentration and a threeway ANOVA (species, time and litter bag) for fungal biomass. Resultados del ANOVA de dos vías (especie y tiempo) para la concentración de nitrógeno $(N)$ y fósforo $(P)$ y el ANOVA de tres vías (especie, tiempo y bolsa de descomposición) para la biomasa fúngica.

\begin{tabular}{lccc}
\hline Source of variability & df & F & $p$ \\
\hline N $(\%)$ & 3 & 84.8 & $<\mathbf{0 . 0 0 0 1}$ \\
$\quad$ Species & 4 & 72.7 & $<\mathbf{0 . 0 0 0 1}$ \\
$\quad$ Time & 12 & 9.2 & $<\mathbf{0 . 0 0 0 1}$ \\
$\quad$ Species $\times$ time & & & \\
P $(\%) \quad 3$ & 76.7 & $<\mathbf{0 . 0 0 0 1}$ \\
$\quad$ Species & 4 & 11.4 & $<\mathbf{0 . 0 0 0 1}$ \\
$\quad$ Time & 12 & 4.6 & $<\mathbf{0 . 0 0 0 1}$ \\
$\quad$ Species $\times$ time & & & \\
Fungal biomass & & & \\
(mg dry mass $\left.{ }^{-1}\right)$ & 3 & 20.2 & $<\mathbf{0 . 0 0 0 1}$ \\
Species & 2 & 19.2 & $<\mathbf{0 . 0 0 0 1}$ \\
$\quad$ Time & 1 & 33.5 & $<\mathbf{0 . 0 0 0 1}$ \\
Litter bag & 6 & 17.3 & $<\mathbf{0 . 0 0 0 1}$ \\
Species $\times$ time & 3 & 2.3 & 0.0922 \\
Species $\times$ litter bag & 2 & 2.7 & 0.0711 \\
Time $\times$ litter bag & 6 & 4.7 & $\mathbf{0 . 0 0 0 7}$ \\
Species $\times$ time $\times$ litter bag & & &
\end{tabular}

tion (isoMDS algorithm in R) and perMANOVA (Adonis algorithm in R) analyses, while JMP, Version 7 (SAS Institute Inc., Cary, NC, 19892007), was used for the rest of the analyses.

\section{RESULTS}

\section{Stream characteristics}

The mean \pm SE properties of the study stream were as follows: stream wetted width $=2.23 \pm$ $0.11 \mathrm{~m}(n=21)$; depth $=16 \pm 1 \mathrm{~cm}(n=157)$; current velocity $=0.25 \pm 0.02 \mathrm{~m} / \mathrm{s}(n=157)$; water conductivity $=607.4 \pm 18.9 \mu \mathrm{s} / \mathrm{cm}(n=5)$; $\mathrm{pH}=8.05 \pm 0.04(n=5)$; water minimum and maximum temperatures $=5^{\circ} \mathrm{C}$ and $13{ }^{\circ} \mathrm{C}$, respectively; and nutrient concentrations $=2.9 \pm 0.5 \mathrm{mg}$ $\mathrm{NO}_{3}-\mathrm{N} \mathrm{l}^{-1}, 0.17 \pm 0.03 \mathrm{mg} \mathrm{NH}_{4}-\mathrm{N} \mathrm{l}^{-1}$, and $0.06 \pm 0.01 \mathrm{mg} \mathrm{PO}_{4}-\mathrm{Pl}^{-1}(n=5)$. Therefore, our stream was $\mathrm{P}$ limited $(\mathrm{N}: \mathrm{P}>40)$.

\section{Leaf traits}

A. altissima leaves showed relatively low lignin and ADF concentration and high $\mathrm{N}, \mathrm{P}$ and TPC concentrations (Table 1). By contrast, $R$. pseudoacacia leaves showed relatively low $\mathrm{P}$, the highest $\mathrm{N}$ and relatively high concentrations of lignin, ADF and TPC. F. angustifolia leaves showed similar properties to A. altissima, except for the lower N and TPC. P. alba leaves exhibited high lignin, ADF and TPC concentrations and low $\mathrm{N}$ and $\mathrm{P}$.

\section{Leaf litter decomposition}

The ranking of litter species by $k_{\mathrm{C}}$ (in the presence of macroinvertebrates) was: A. altissima $=F$. angustifolia $>P$. alba $>R$. pseudoacacia, while the ranking by $k_{\mathrm{F}}$ (in absence of macroinvertebrates) was: A. altissima $>F$. angustifolia $>$ P. alba $>$ R. pseudoacacia (Table 2; Figs. 1a-b). All of the species, except $A$. altissima, showed significantly greater $k_{\mathrm{C}}$ than $k_{\mathrm{F}}$ (Table 2). The interaction terms (species $\times$ time) and (litter bag $\times$ time) were highly significant (ANCOVA; $F_{3,121}=49.4$, and $F_{1,123}=56.1$, respectively; $p<0.0001$ ), indicating that both factors (species and litter bag) had significant effects on the decomposition rates (Figs. 1a-b). In addition, the interaction term (species $\times$ litter bag $\times$ time) was also significant (ANCOVA, $F_{3,124}=3.67$, $p=0.014)$, indicating that the effect of the litter bag in the decomposition rates was different among species. The contribution of macroinvertebrates to decomposition (ratio $k_{\mathrm{C}}: k_{\mathrm{F}}$ ) was greater in native than in exotic leaf litters (Table 2). The $k_{\mathrm{C}}$ was negatively correlated with lignin (\%), ADF (\%), N:P ratio and lignin:P (Pearson correlation; $r=-0.82, \quad r=-0.77, \quad r=-0.73$ and $r=-0.86$, respectively; $p<0.05)$. The $k_{\mathrm{C}}$ was positively correlated with $\mathrm{P}(\%)$ (Pearson correlation; $r=0.66 ; p<0.05)$. The $k_{\mathrm{F}}$ was negatively correlated with lignin (\%), ADF (\%) and lignin:P (Pearson correlation; $r=-0.86$, $r=-0.81$ and $r=-0.75$, respectively; $p<0.05$ ), but no significant correlations were found between decomposition rates and the rest of leaf traits considered (N, TPC, and lignin:N). 


\section{Fungal biomass}

Fungal biomass buildup on the decomposing leaves was affected by species, time, litter bag $(\mathrm{C}$ and $\mathrm{F})$ and most of the interactions (Table 3). Native leaf litter had a higher fungal biomass than exotic leaf litter (ANOVA, Tukey HSD, $p<0.05$; Figs. 1c-d). In the presence of macroinvertebrates (C-bags), the differences in the fungal biomass between exotic and native leaves were mainly due to the greater value in the native $F$. angustifolia at 20 days and the greater value in $P$. alba than in R. pseudoacacia at 62 days (ANOVA, Tukey HSD, $p<0.05$; Fig. 1c). However, in the absence of macroinvertebrates (F-bags), both exotics showed a lower fungal biomass than natives at 39 days and 62 days (ANOVA, Tukey HSD, $p<0.05$; Fig. 1d). In F-bags, the fungal biomass was lower than in Cbags, but only significant in the case of $F$. angustifolia (ANOVA, Tukey HSD, $p<0.05$; Figs. 1c-d). The fungal biomass did not vary significantly throughout the study for the two exotic species in any bag type ( $\mathrm{C}$ and $\mathrm{F}$ ) (ANOVA, Tukey HSD, $p>0.05$; Figs. 1c-d), but peaks were observed for the two natives at 20 days $(F$. angustifolia) and at 62 days (P. alba) (ANOVA, Tukey HSD, $p<0.05$; Figs. 1c-d).

\section{Nutrient dynamics}

Litter $\mathrm{N}$ and $\mathrm{P}$ concentrations were influenced by species, time and the interaction between them
(Table 3). Leaves of R. pseudoacacia showed the highest $\mathrm{N}$ and lowest $\mathrm{P}$ concentrations throughout the experiment (ANOVA, Tukey HSD, $p<0.05$; Figs. 2a-b). N concentration increased in the second collection (20 days) in all of the species and then decreased in A. altissima and $F$. angustifolia. The $\mathrm{N}$ concentration kept increasing in $P$. alba and remained unchanged in $R$. pseudoacacia (ANOVA, Tukey HSD, $p<0.05$; Fig. 2a). In the first collection (day 2), the $\mathrm{P}$ concentration decreased and then increased over time in $P$. alba leaves, but no variation was observed for the other leaf species (ANOVA, Tukey HSD, Fig. 2b).

\section{Macroinvertebrate colonization}

The most abundant macroinvertebrate families in the study in the NE bags were: Chironomidae (Diptera), Gammaridae (Amphipoda), Bithyniidae (Mollusca), Hydropsychidae (Trichoptera), Baetidae (Ephemeroptera) and Simuliidae (Diptera) that made up $28 \%, 23 \%, 12 \%, 10 \%, 8 \%$ and $5 \%$, respectively, of the total macroinvertebrate abundance. The total macroinvertebrate density and family richness did not vary across species (ANOVA, $F_{4,84}=1.75, \quad F_{4,84}=1.61$, respectively, $p>0.05)$ or time $\left(F_{4,84}=1.52\right.$, $F_{4,84}=2.04$, respectively, $p>0.05$ ) but were affected by its interaction $\left(F_{16,84}=4.67\right.$, $F_{16,84}=3.07$, respectively, $p<0.05$; Figs. 3a-b). Therefore, the density and richness of the macroinvertebrate families varied in different ways over
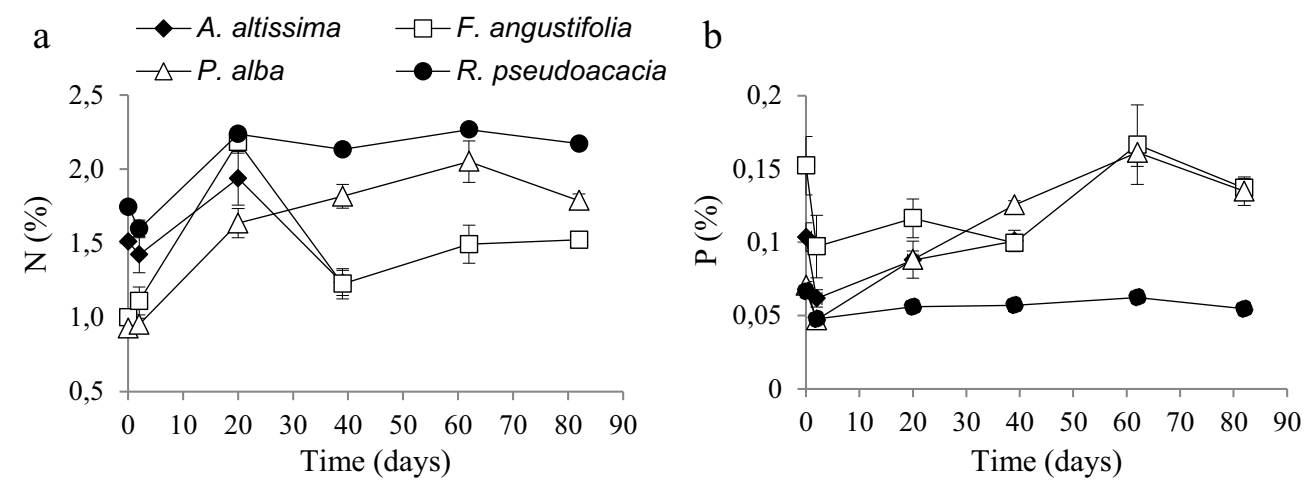

Figure 2. The mean $( \pm \mathrm{SE})$ leaf $\mathrm{N}(\mathrm{a})$ and $\mathrm{P}(\mathrm{b})$ concentrations for each species over the study period. Black symbols indicate exotic species and white symbols indicate native species. Media $( \pm$ EE) de las concentraciones de $N(a)$ y $P(b)$ en las hojas para cada especie en el periodo de estudio. Los símbolos negros indican especies exóticas y los blancos especies nativas. 

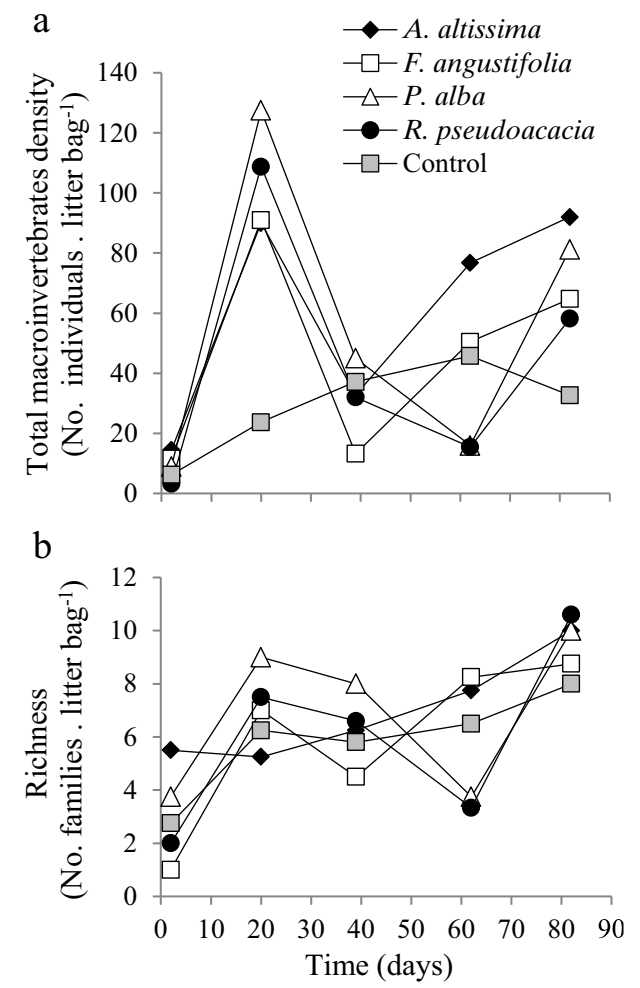

Figure 3. The mean density (a) and richness (b) of macroinvertebrates for each species over the study period. Black symbols indicate exotic species, white symbols indicate native species and grey symbols indicate empty bags (control). SE is not shown for better clarity. Media de la densidad (a) y riqueza (b) de macroinvertebrados para cada especie a lo largo del periodo de estudio. Los símbolos negros indican especies exóticas, los blancos especies nativas y los grises bolsas vacías (controles). EE no se muestra para una mejor claridad.

time. The macroinvertebrate density drastically dropped in the third collection (Fig. 3a), likely due to the sudden rise of flow mentioned above, which may have dragged many of the macroinvertebrates that had already colonized the litter bags. Subsequently, the macroinvertebrate density increased in the leaf litters with faster decomposition (A. altissima and $F$. angustifolia), but decreased in those with slower decomposition (P. alba and R. pseudoacacia) (Fig. 3a). A similar pattern appeared in family richness, which increased in A. altissima and $F$. angustifolia and decreased in $P$. alba and $R$. pseudoacacia from 39 days to 62 days (Fig. 3b). However, the relative abundance of shredders did not differ across species, time or its interaction (GLM, $\chi^{2}=1.12$, $\chi^{2}=1.39, \chi^{2}=3.85$, respectively, $p>0.05$ ).
The first axis of the NMDS was negatively correlated with the abundance of Gammaridae (Amphipoda) and positively correlated with the abundance of Chironomidae (Diptera) (Fig. 4b). Axis 2 was negatively correlated with the abundance of Bithyniidae (Mollusca) and Chironomidae and positively correlated with the abundance of Simuliidae (Diptera), Perlodidae (Plecoptera) and Hydropsychidae (Trichoptera) (Fig. 4b). The NMDS biplots showed that macroinvertebrates from the four leaf species appeared close to each other in the first three collections, except those of $P$. alba, which appeared separated from the other species in the first collection (Fig. 4a). On the contrary, samples of the two last collections were scattered throughout the ordination axes. In the fourth collection, after 62 days in the stream, samples corresponding to native leaves appeared clustered and separated from those corresponding to the exotic leaves. In the fifth collection, after 82 days in the stream, P. alba and R. pseudoacacia samples appeared clustered and far from A. altissima and $F$. angustifolia along axis 1 of the NMDS. However, the perMANOVA showed that only time significantly affected the composition of macroinvertebrate families $\left(F_{4,84}=4.09\right.$, $p<0.05)$.

\section{DISCUSSION}

Riparian invasion by exotic trees implies that streams receive inputs of leaves with properties that may widely differ from the native leaves, which may alter the structure and function of aquatic communities (Webster et al., 1990). Our study showed that 1) fungal colonization was lower in exotic than in the native leaf litter and 2) the contribution of macroinvertebrates to leaf decomposition (as reflected by $k_{\mathrm{C}}: k_{\mathrm{F}}$ ) was more important in native than in exotic leaves, although no differences were found in the macroinvertebrate density. In accordance with the NWH, fungi may better colonize the litter from those species they have co-evolved with, and macroinvertebrates may lower the effect on exotic leaves because they are not pre-adapted to their secondary compounds (Callaway \& Ridenour, 2004; 
a $\begin{array}{ll}\bullet \text { A. altissima } & \square \text { F. angustifolia } \\ \triangle P \text {. alba } & \bullet \text { R. pseudoacacia }\end{array}$

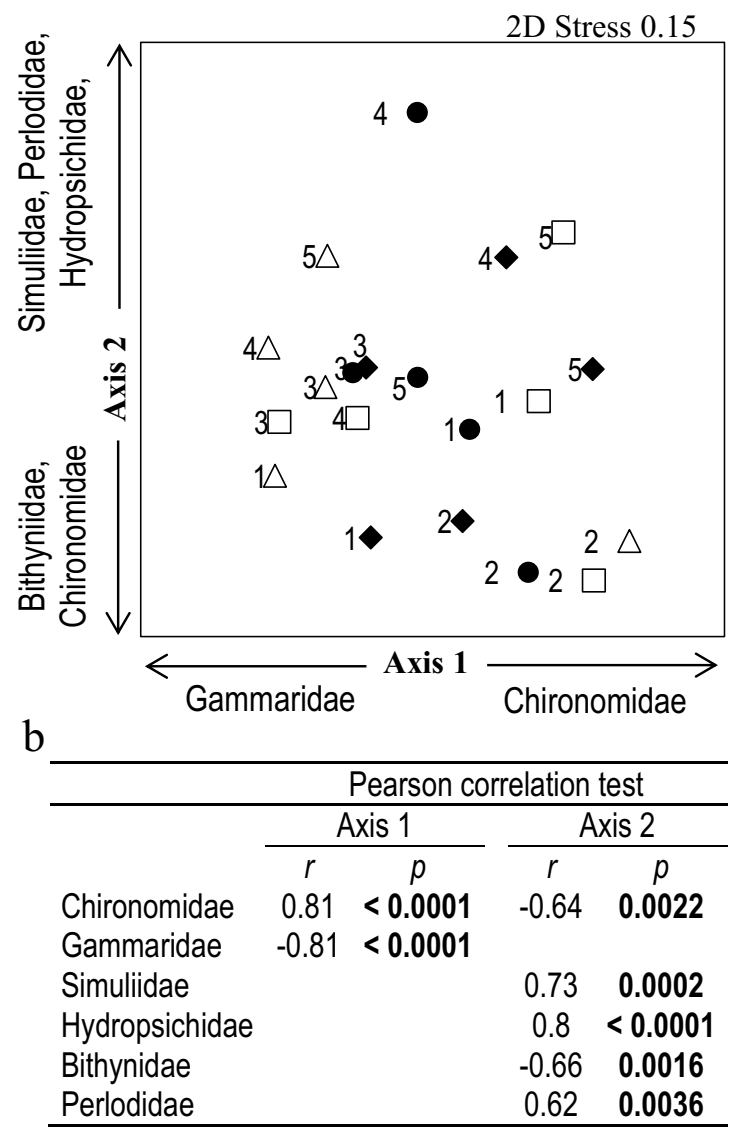

Figure 4. (a) Two dimensional Non Metric Multidimensional Scaling (NMDS) for C-bags using the mean relative abundances of macroinvertebrate families per leaf species and collection time. The symbols represent different species. Black symbols indicate exotic species and white symbols indicate native species. The numbers next to the symbols designate collection times $(1=2$ days, $2=20$ days, $3=39$ days, $4=62$ days, $5=82$ days). (b) Pearson correlation test between mean relative abundance of macroinvertebrate families and NMDS axis. Significant correlations $(p<0.05)$ are indicated in bold. $(a)$ Escalamiento Multidimensional No Métrico (NMDS) en dos dimensiones para las bolsas de descomposición C usando la media de las abundancias relativas de las familias de macroinvertebrados por especie de hoja y tiempo de colecta. Los símbolos representan diferentes especies. Símbolos en negro indican especies exóticas y en blanco especies nativas. Los números junto a los símbolos indican tiempos de colecta $(1=2$ días, $2=20$ días, 3 = 39 días, 4 = 62 días, $5=82$ días). (b) Test de correlación de Pearson entre la media de las abundancias relativas de las familias de macroinvertebrados y los ejes del NMDS. Las diferencias significativas ( $\mathrm{p}<0.05$ ) están indicadas en negrita.

Gama et al., 2014). Moreover, the greater fungal colonization may also explain the greater ef- fect of macroinvertebrates on native leaves than on exotic leaves because macroinvertebrates usually prefer more leaves preconditioned by microorganisms (Wright \& Covich, 2005). Finally, the $k_{\mathrm{C}}: k_{\mathrm{F}}$ ratio, indicating the balance in the contribution of microorganisms and detritivorous macroinvertebrates, accounted for the responses to different leaf litter quality (Gessner \& Chauvet, 2002). This balance changed in the presence of A. altissima and $R$. pseudoacacia leaf litter, which differed in quality from that of native species.

Given that fungi and macroinvertebrates are important agents involved in leaf litter decomposition (Abelho, 2001; Cornut et al., 2010) and they affected the exotic litter less than the native litter, slower decomposition rates $(k)$ would also be expected for exotic leaves rather than for native leaves. However, physical-chemical differences across leaf species better explained the differences in $k$ than their origin (exotic vs. native), in accordance with previous studies (Hladyz et al., 2009; Bottollier-Curtet et al., 2011; Casas et al., 2013). The ranking of $\mathrm{k}$ in the presence of macroinvertebrates was $A$. altissima $=F$. angustifolia $>P$. alba $>$ R. pseudoacacia, slightly different from the ranking found in their absence $(A$. altissima $>F$. angustifolia $>P$. alba $>R$. pseudoacacia). Lignin, ADF and lignin:P were good predictors of $k$ in the presence of macroinvertebrates $\left(k_{\mathrm{C}}\right)$ and in their absence $\left(k_{\mathrm{F}}\right)$, as previously reported (Ostrofsky, 1997; Hladyz et al., 2009). Moreover, the leaf $\mathrm{P}$ and $\mathrm{N}: \mathrm{P}$ ratio were also important in determining $k_{\mathrm{C}}$, according to Hladyz et al. (2009). Physical abrasion by stream water flow is also an important factor determining leaf decomposition (Abelho, 2001). For instance, the fibres, such as lignin or ADF, increased the resistance of leaf lamina to fracture, which in turn determined the lower effect of water flow on $k$ (Choong et al., 1992). Consequently, A. altissima and $F$. angustifolia leaves, which presented the lowest ADF and lignin concentrations, decomposed faster than leaves of the other species.

According to NWH, the presence of secondary compounds in the leaves of both exotics, such as robinetin, myricetin and quercetin in $R$. pseudoacacia (Nasir et al., 2005), and ailantho- 
ne, chaparrine, and ailanthinol $\mathrm{B}$ in A. altissima (De Feo et al., 2003), may explain their poor fungal colonization. Phytotoxic compounds of other species were found to inhibit microbiological activity in soils (Llinares et al., 1993), and essential oils from Eucalyptus globulus may also delay fungal growth (Graça et al., 2002). Fungal biomass was reported as a good predictor of $k$ (Hladyz et al., 2009) and could explain why the native litter from $P$. alba decomposed faster than that from the exotic $R$. pseudoacacia, even when they had similar fibre concentrations. The high fungal biomass found in $F$. angustifolia leaves at 20 days of stream immersion was probably due to its low phenolic concentration because phenolic compounds may depress fungal growth (Mathuriau \& Chauvet, 2002). Moreover, fungi could take nutrients from the water column to compensate for the effect of low-quality litter in streams with high nutrient levels (Gulis \& Suberkropp, 2003). Therefore, given that our stream was P-limited $(\mathrm{N}: \mathrm{P}>40)$, the high $\mathrm{P}$ content of $F$. angustifolia leaves may additionally contribute to a high colonization by fungi. Accordingly, we found that the $\mathrm{P}$ concentration in leaves had a positive effect on decomposition rates. $F$. angustifolia leaves decomposed slower than A. altissima in the absence (F-bags), but not in the presence (C-bags), of macroinvertebrates, probably because the fungal colonization in $F$. angustifolia leaves was greater in F-bags than in C-bags. The overall lower fungal biomass found in F-bags compared with C-bags could be explained by two non-exclusive arguments. First, given that aquatic hyphomycetes (the main microbial decomposers in streams; Gulis \& Suberkropp, 2003) are sensitive to oxygen availability (Medeiros et al., 2009), poor oxygen diffusion into F-bags, due to the smaller mesh size, may have hampered the colonization of litter by this group of microbes. Second, macroinvertebrates may enhance fungal development on leaf litter, as their faeces represent a source of food for fungi (Villanueva et al., 2012).

Although we found similar or greater $\mathrm{k}$ of A. altissima than that of $F$. angustifolia in the stream, Alonso et al. (2010) found the contrary in a man-made lake. This suggested a higher vul- nerability of A. altissima leaves to physical abrasion by the stream water flow. In fact, A. altissima presented soft leaves (Swan et al., 2008), which acquired a gelatinous consistency during decomposition (personal observation), and the $\mathrm{k}$ of soft leaves were enhanced by the water flow (Abelho, 2001). In addition, the absence of shredders in the man-made lake made microbial decomposition more relevant (Alonso et al., 2010), which may favour the decomposition of $F$. angustifolia over A. altissima, since, as reported above, the native species may buildup greater fungal biomass than the exotic species.

Decomposition rates may vary across streams with different characteristics, such as temperature, nutrient levels, macroinvertebrates or riparian vegetation (Grubbs \& Cummins, 1994; Pérez et al., 2011; Menéndez et al., 2011). For instance, Casas et al., (2013) found that $k$ was greater in streams receiving lower quality litter than in streams receiving higher quality litter from the riparian vegetation. However, the differences in k among leaves from Alnus glutinosa L., Quercus pyrenaica Wild, Pinus radiata D. Don., and Platanus hispanica Mill. ex Münchh. remained unaltered across streams, as the quality of litter was the most important factor determining these differences (Casas et al., 2013). This suggested that in our study, the differences found in $\mathrm{k}$ among species would be extensible to other streams. Decomposition rates may also vary among seasons due to changes in water temperature or in the structure of the macroinvertebrate community (Pérez et al., 2011). The four leaf species used in our study have their leaf litterfall peaks in autumn, which makes the choice of that season more relevant under an ecological perspective.

Increases in the $\mathrm{N}$ litter concentration over the decomposition process could be attributed to microorganism's $\mathrm{N}$ uptake from the water column and subsequent immobilization in form of the microbial biomass (Kuehn et al., 2000). Additionally, a faster loss of N-rich than N-poor leaf litter compounds may occur during decomposition. The greater $\mathrm{N}$ concentration observed in $R$. pseudoacacia litter throughout the experiment suggested that the organic $\mathrm{N}$ concentration 
may increase in the stream upon invasion by this species, as reported for the $\mathrm{N}$-fixing species Elaeagnus angustifolia (Mineau et al., 2011). Furthermore, nitrate accumulation was reported in wetlands adjacent to $R$. pseudoacacia stands (Williard et al., 2005). Therefore, if R. pseudoacacia invaded riparian zones lacking native $\mathrm{N}$-fixing trees, stream $\mathrm{N}$ would increase.

We found no differences in the relative abundance of shredders, total density and the richness of macroinvertebrates across the leaves of different species, suggesting that macroinvertebrates were able to use both exotic and native leaves, either as refuge or food, as reported by other studies (Albariño \& Balseiro, 2002). The density of macroinvertebrates drastically dropped after the hydropeaking event that occurred in the middle of the study period. Similarly, in a regulated stream, Mendoza-Lera et al. (2010) found that after water discharges, the density and biomass of macroinvertebrates decreased, which slowed down decomposition. This suggested that hydropeaking events may affect, to a greater extent, leaf species whose decomposition is mainly determined by macroinvertebrates. This fact could be important in regulated streams, which are frequently impacted by hydropeakings.

The macroinvertebrate community varied highly during the study period across collections but not across species. However, we could note some different trends at the final stages of decomposition, likely due to different leaf chemistry, fungal leaf preconditioning and/or availability of remaining material (Casas \& Gessner, 1999). For instance, the weight of the Chironomidae (collector-gatherer) family, which feed on depositional fine particulate organic matter (FPOM), was higher in litter bags with little or no remaining mass (A. altissima at 62 days and 82 days and $F$. angustifolia at 82 days). At 62 days in the stream, Gammaridae (shredder) were dominant in native leaves, contrasting with the high weight of Simuliidae, Perlodidae and Hydropsychidae in $R$. pseudoacacia leaves. The most abundant families found in $R$. pseudoacacia litter bags at 62 days corresponded to functional feeding groups which did not feed directly on leaves (i.e., collector-filterers and predators), suggesting that they used $R$. pseudoacacia leaves as a refuge or as a source of prey. By contrast, the Gammaridae family preferentially consumed fungal pre-conditioned leaves (Graça et al., 1993; Foucreau et al., 2013), explaining the high weight of Gammaridae in P. alba leaves, which were more colonized by fungi than $R$. pseudoacacia. This result may also account for the co-evolution of Gammaridae with the associated fungal species in $P$. alba leaves (according to $\mathrm{NWH}$ ) because fungal species composition in the leaves determined the feeding activity of a variety of shredders (Arsuffi \& Suberkropp, 1989). Therefore, the Gammaridae family may be negatively affected if $P$. alba was eventually displaced by exotic trees.

Because the differences in leaf decomposition among species were species-specific, the consequences of the exotic species on $\mathrm{k}$ will depend on the prevailing native species of the invaded ecosystem. For instance, a greater impact on $k$ can be expected if $A$. altissima replaces vegetation dominated by $P$. alba (decomposition would be accelerated) and if $R$. pseudoacacia replaces vegetation dominated by $F$. angustifolia (decomposition would slow down). Given the fast decomposition of A. altissima, a riparian invasion by this species may reduce the time of food availability to shredder macroinvertebrates (Wallace et al., 1999), affecting their life cycle, particularly in those species where the major growth period occurs in late autumn and winter (e.g., many Trichoptera) (Anderson \& Cummins, 1979).

In conclusion, this study showed the potential impact of the displacement of native vegetation (characterized by $P$. alba and/or F. angustifolia) by the exotics $A$. altissima and/or $R$. pseudoacacia in a headwater stream ecosystem. The exotic A. altissima may increase decomposition rates, while $R$. pseudoacacia would have the reverse effect. The intensity of these impacts depends on the native vegetation that they replace. Leaf species and their chemical characteristics (mainly fibre concentration and phosphorous) controlled the within-stream leaf decomposition. Moreover, leaves of both exotic species were less colonized by fungi, which may affect macroinvertebrates that feed on preconditioned 
leaves. The Gammaridae family could be one of the most affected because they tended to have a higher weight on the macroinvertebrate community, colonizing more leaves of $P$. alba than other species. The NWH could explain the lower fungal colonization and lower effect of macroinvertebrates on litter decomposition in exotic species than in native species, while the contrasting decomposition rates among species could mainly be explained by the litter quality.

\section{ACKNOWLEDGEMENTS}

This study was supported by the projects CGL2011-16388/BOS of the Ministerio de Economía y Competitividad of Spain and POII100179-4700 of the Junta de Comunidades de Castilla-La Mancha. Silvia Medina Villar was supported by a grant from the Ministerio de Economía y Competitividad of Spain (FPI fellowship, BES-2011-048379). We acknowledge Maria B. Langa Morales for her support in performing this experiment. We are grateful to the support of the REMEDINAL-2 network (Comunidad de Madrid).

\section{REFERENCES}

ABELHO, M. 2001. From litterfall to breakdown in streams: A Review. The Scientific World, 1: 656680.

ALBARIÑO, R. J. \& E. G. BALSEIRO. 2002. Leaf litter breakdown in Patagonian streams: native versus exotic trees and the effect of invertebrate size. Aquatic Conservation: Marine and Freshwater Ecosystems, 12: 181-192.

ALONSO, A., N. GONZÁLEZ-MUÑOZ \& P. CASTRO-DÍEZ. 2010. Comparison of leaf decomposition and macroinvertebrate colonization between exotic and native trees in a freshwater ecosystem. Ecological Research, 25: 647-653.

ANDERSON, N. H. \& K. W. CUMMINS. 1979. Influences of diet on the life histories of aquatic insects. Journal of the Fisheries Research Board of Canada, 36: 335-342.

ARSUFFI, T. L. \& K. SUBERKROPP. 1989. Selective feeding by shredders on leaf-colonizing stream fungi: comparison of macroinvertebrate taxa. Oecologia, 79: 30-37.

BAILEY, J. K., J. A. SCHWEITZER \& T. G. WHITHAM. 2001. Salt cedar negatively affects biodiversity of aquatic macroinvertebrates. Wetlands, 21: 442-447.

BOTTOLLIER-CURTET, M., J. CHARCOSSET, A. PLANTY-TABACCHI \& E. TABACCHI. 2011. Degradation of native and exotic riparian plant leaf litter in a floodplain pond. Freshwater Biology, 56 (9): 1798-1810.

CALLAWAY, R. M. \& W. M. RIDENOUR. 2004. Novel weapons: invasive success and the evolution of increased competitive ability. Frontiers in Ecology and the Environment, 2: 436-443.

CASAS, J. J. \& M. O. GESSNER. 1999. Leaf litter breakdown in a Mediterranean stream characterized by travertine precipitation. Freshwater Biology, 41: 781-793.

CASAS, J. J, A. LARRAÑAGA, A., M. MENÉNDEZ, J. M., POZO, J., A. BASAGUREN, A., A. MARTÍNEZ, J. A., PÉREZ, J., J. M. GONZÁLEZ, J. M., S. MOLLÁ, S.,C. CASADO, C., E. DESCALS, E., N. ROBLAS, J. A. N., LÓPEZGONZÁLEZ, J. A. \& J. L. VALENZUELA. 2013. Leaf litter decomposition of native and introduced tree species of contrasting quality in headwater streams: How does the regional setting matter? Science of Total Environment, 458-460: 197-208.

CASTRO-DÍEZ, P., N. FIERRO-BRUNNENMEISTER, N. GONZÁLEZ-MUÑOZ \& A. GALLARDO. 2011. Effects of exotic and native tree leaf litter on soil properties of two contrasting sites in the Iberian Peninsula. Plant and Soil, 350: 179-191.

CHOONG, M. F., P. W. LUCAS, J. S. Y. ONG, B. PEREIRA, H. T. W. TAN \& I. M. TURNER. 1992. Leaf fracture toughness and sclerophylly: their correlation and ecological implications. New Phytologist, 121: 597-610.

CHYTRÝ, M., L. C. MASKELL, J. PINO, P. PYŠEK, M. VILÀ, X. FONT \& S. M. SMART. 2008. Habitat invasions by alien plants: a quantitative comparison between Mediterranean, subcontinental and oceanic regions of Europe. Journal of Applied Ecology, 45: 448-458.

CIERJACKS, A., I. KOWARIK, J. JOSHI, S. HEMPEL, M. RISTOW, M. VON DER LIPPE \& E. WEBER. 2013. Biological Flora of the British Isles: Robinia pseudoacacia. Journal of Ecology, 101: 1623-1640. 
CORNUT, J., A. ELGER, D. LAMBRIGOT, P. MARMONIER \& E. CHAUVET. 2010. Early stages of leaf decomposition are mediated by aquatic fungi in the hyporheic zone of woodland streams. Freshwater Biology, 55: 2541-2556.

DAISIE. 2009. European Invasive Alien Species Gateway Available at http://www.europe-aliens.org [accessed 06 November 2013]

DE FEO, V., L. DE MARTINO, E. QUARANTA \& C. PIZZA. 2003. Isolation of phytotoxic compounds from tree-of-heaven (Ailanthus altissima Swingle). Journal of Agricultural and Food Chemistry, 51: 1177-1180.

EKBLAD, A., H. WALLANDER \& T. NASHOLM. 1998. Chitin and ergosterol combined to measure total and living fungal biomass in ectomycorrhizas. New Phytologist, 138: 143-149.

ENRIQUEZ, S., C. M. DUARTE \& K. SANDJENSEN. 1993. Patterns in decomposition rates among photosynthetic organisms: the importance of detritus C-N-P content. Oecología, 94: 457-471.

FOUCREAU, N., S. PUIJALON, F. HERVANT \& C. PISCART. 2013. Effect of leaf litter characteristics on leaf conditioning and consumption by Gammarus pulex. Freshwater Biology, 58: 1672-1681.

GAMA, M., L. GUILHERMINO \& C. CANHOTO. 2014. Comparison of three shredders response to acute stress induced by eucalyptus leaf leachates and copper: single and combined exposure at two distinct temperatures. Annales de LimnologieInternational Journal of Limnology, 50: 97-107.

GEIB. 2006. TOP 20: Las especies exóticas invasoras más dañinas presentes en España GEIB, Serie Técnica N.2. 116.

GESSNER, M. O. 2005. Ergosterol as a measure of fungal biomass. In: Methods to Study Litter Decomposition: A Practical Guide. M. A. S. Graça, F. Bärlocher \& M. O. Gessner (eds.): 189-196. The Netherlands.

GESSNER, M. O. \& E. CHAUVET. 1993. Ergosterolto-biomass conversion factors for aquatic hyphomycetes. Applied and Environmental Microbiology, 85: 377-384.

GESSNER, M. O. \& E. CHAUVET. 2002. A case for using litter breakdown to assess functional stream integrity. Ecological Applications, 12: 498-510.

GOERING, H. K. \& P. J. VAN SOEST. 1970. Forage fiber analysis (apparatus, reagents, procedures and some applications). In: Agricultural Handbook, 379. USDA Agricultural Research Service.
GOING, B. M. \& T. L. DUDLEY. 2008. Invasive riparian plant litter alters aquatic insect growth. Biological Invasions, 10: 1041-1051.

GRAÇA, M. A. S., L. MALTBY \& P. CALOW. 1993. Importance of fungi in the diet of Gammarus pulex and Asellus aquaticus I: feeding strategies. Oecologia, 93: 139-144.

GRAÇA, M. A. S., J. POZO, C. CANHOTO \& A. ELOSEGI. 2002. Effects of Eucalyptus plantations on detritus, decomposers, and detritivores in streams. Scientific World Journal, 30 (2): 1173-85.

GRAÇA, M. A. S. \& C. CANHOTO. 2006. Leaf litter processing in low order streams. Limnetica, 25 (12): $1-10$.

GRAHAM, H. D. 1992. Stabilization of the prussian blue color in the determination of polyphenols. Journal of Agriculture and Food Chemistry, 40: 801-805.

GRUBBS, S. A. \& K. W. CUMMINS. 1994. Processing and macroinvertebrate colonization of black cherry (Prunus serotina) leaves in two streams differing in summer biota, thermal regime and riparian vegetation. American Midland Naturalist, 132: 284-293.

GULIS, V. \& A. SUBERKROPP. 2003. Leaf litter decomposition and microbial activity in nutrientenriched and unaltered reaches of a headwater stream. Freshwater Biology, 48: 123-134.

HLADYZ, S., M. O. GESSNER, P. S. GILLER, J. POZO \& G. WOODWARD. 2009. Resource quality and stoichiometric constraints on stream ecosystem functioning. Freshwater Biology, 54: 957-970.

HOOD, W. G. \& R. J. NAIMAN. 2000. Vulnerability of riparian zones to invasion by exotic vascular plants. Plant Ecology, 148: 105-114.

KOWARIK, I. \& I. SÄUMEL. 2007. Biological flora of Central Europe: Ailanthus altissima (Mill.) Swingle. Perspectives in Plant Ecology Evolution and Systematics, 8: 207-237.

KUEHN, K. A., M. J. LEMKE, R. G. WETZEL \& K. SUBERKROPP. 2000. Microbial biomass and production associated with decaying leaf litter of the emergent macrophyte Juncus effusus. Limnology and Oceanography, 45: 862-870.

LARRAÑAGA, A., A. BASAGUREN \& J. POZO. 2009. Impacts of Eucalyptus globulus plantations on physiology and population densities of invertebrates inhabiting Iberian Atlantic Streams. International Review of Hydrobiology, 94: 497-511. 
LINDIG-CISNEROS, R. A. \& J. B. ZEDLER. 2001. Effect of light on Phalaris arundinacea L. germination. Plant Ecology, 155: 75-78.

LLINARES, F., D. MUÑOZ-MINGARRO, J. M. POZUELO, B. RAMOS \& F. B. DE CASTRO. 1993. Microbial inhibition and nitrification potential in soils incubated with Elaeagnus angustifolia L. leaf litter. Geomicrobiology Journal, 11: 149-156.

MATHURIAU, C. \& E. CHAUVET. 2002. Breakdown of leaf litter in a neotropical stream. Journal of the North American Benthological Society, 21: 384-396.

MCCUNE, B. \& J. B. GRACE. 2002. Analysis of ecological communities. MjM Software, Gleneden Beach, Oregon, USA (www.pcord.com).

MEDEIROS, O., C. PASCOAL \& M. A. S. GRAÇA. 2009. Diversity and activity of aquatic fungi under low oxygen conditions. Freshwater Biology, 54: 142-149.

MENDOZA-LERA, C. A., LARRAÑAGA, J. PÉREZ, E. DESCALS, A. MARTÍNEZ, O. MOYA, I. AROSTEGUI \& J. POZO. 2010. Headwater reservoirs weaken terrestrial-aquatic linkage by slowing leaf-litter processing in downstream regulated reaches. River Research and Applications, 28 (1): 13-22.

MENÉNDEZ, M., E. DESCALS, T. RIERA \& O. MOYA. 2011. Leaf litter breakdown in Mediterranean streams: effect of dissolved inorganic nutrients. Hydrobiologia, 669: 143-155.

MERRITT, R. W. \& K. W. CUMMINS. 1996. An introduction to the aquatic insects of North America. 3rd Edn. (Kendall/Hunt Publishing Company, Dubuque).

MINEAU, M. M., C. V. BAXTER \& A. M. MARCARELLI. 2011. A non-native riparian tree (Elaeagnus angustifolia) changes nutrient dynamics in streams. Ecosystems, 14: 353-365.

MOTOMORI, K., H. MITSUHASHI \& S. NAKANO. 2001. Influence of leaf litter quality on the colonization and consumption of stream invertebrate shredders. Ecological Research, 16: 173-182.

NASIR, H., Z. IQBAL, S. HIRADATE \& Y. FUJII. 2005. Allelopathic potential of Robinia pseudoacacia L. Journal of Chemical Ecology, 31: 21792192.

NELSON, D. W. \& L. E. SOMMERS. 1973. Determination of total nitrogen in plant material. Agronomy Journal, 65: 109-112.
OSTROFSKY, M. L. 1997. Relationship between chemical characteristics of autumn-shed leaves and aquatic processing rates. Journal of North American Benthological Society, 16: 750-759.

PÉREZ, J., M. MENÉNDEZ, S. LARRAÑAGA \& J. POZO. 2011. Inter- and Intra-Regional Variability of Leaf Litter Breakdown in Reference Headwater Streams of Northern Spain: Atlantic versus Mediterranean Streams. International Review of Hydrobiology, 96: 105-117.

PLANTY-TABACCHI, A. M., E. TABACCHI, R. J. NAIMAN, C. DEFERRARI \& H. DÉCAMPS. 1996. Invasibility of species-rich communities in riparian zones. Conservation Biology, 10: 598-607.

R DEVELOPMENT CORE TEAM 2011. $R$ : A language and environment for statistical computing. R Foundation for Statistical Computing, Vienna, Austria. (http://www.R-project.org/).

READ, M. G. \& L. A. BARMUTA. 1999. Comparisons of benthic communities adjacent to riparian native eucalypt and introduced willow vegetation. Freshwater Biology, 42: 359-374.

RICE, S., B. WESTERMAN B \& R. FEDERICI. 2004. Impacts of the exotic, nitrogen-fixing black locust (Robinia pseudoacacia) on nitrogencycling in a pine-oak ecosystem. Plant Ecology, 174: 97-107.

RINCÓN, J. \& F. MARTÍNEZ. 2006. Food quality and feeding preferences of Phylloicus sp (Trichoptera: Calamoceratidae). Journal of the North American Benthological Society, 25: 209-215.

SANZ-ELORZA, M., E. D. DANA SANCHEZ \& E. SOBRINO-VESPERINAS. 2004. Atlas de las Plantas Alóctonas Invasoras en España. Ministerio de Medio Ambiente, Madrid.

SWAN, C. M., B. HEALEY \& D. C. RICHARDSON. 2008. The role of native riparian tree species in decomposition of invasive tree of heaven (Ailanthus altissima) leaf litter in an urban stream. Ecoscience, 15: 27-35.

TACHET, H., P. RICHOUX, M. BOURNAUD \& P. USSEGLIO-POLATERA. 2003. Invertébrés d'eau douce. Systematique, biologie, écologie. CNRS editions: París, France.

VILLANUEVA, V. D., R. ALBARIÑO \& C. CANHOTO. 2012. Positive effect of shredders on microbial biomass and decomposition in stream microcosms. Freshwater Biology, 57: 2504-2513.

WALLACE, J. B., S. L. EGGERT, J. L. MEYER \& J. R. WEBSTER. 1997. Multiple trophic levels of 
a forest stream linked to terrestrial litter inputs. Science, 277: 102-104.

WALLACE, J. B., S. L. EGGERT, J. L. MEYER \& J. R. WEBSTER. 1999. Effects of resource limitation on a detrital-based ecosystem. Ecological Monographs, 69: 409-442.

WATERMAN, P. G. \& S. MOLE. 1994. Analysis of Phenolic Plant Metabolites. Blackwell Scintific Publications: London, UK.

WEBSTER, J. R. \& E. F. BENFIELD. 1986. Vascular plant breakdown in freshwater ecosystems. Annual Review of Ecology and Systematics, 17: 567-594.

WEBSTER, J. R., S. W. GOLLADAY, E. F. BENFIELD, D. J. D'ANGELO \& G. T. PETERS. 1990.
Effects of forest disturbance on particulate organic matter budgets of small streams. Journal of the North American Benthological Society, 9: 120140.

WILLIARD, K. W. J., D. R. DEWALLE \& P. J. EDWARDS. 2005. Influence of bedrock geology and tree species composition on stream nitrate concentrations in Mid-Appalachian forested watersheds. Water, Air and Soil Pollution, 160: 55-76.

WRIGHT, M. S. \& A. P. COVICH. 2005. Relative importance of bacteria and fungi in a tropical headwater stream: leaf decomposition and invertebrate feeding preference. Microbial Ecology, 49: 536546. 